\title{
PENGARUH PROFITABILITAS, UKURAN PERUSAHAAN, TANGIBILITY, DAN PERTUMBUHAN TERHADAP STRUKTUR MODAL PADA PERBANKAN YANG TERDAFTAR DI BEI PERIODE 2008-2016
}

\author{
Ferdina Watiningsih ${ }^{1)}$ \\ 1) dosen universitas pamulang, email : erdinaw@gmail.com
}

\section{ARTICLES INFORMATION}

\section{JURNAL SEKURITAS \\ (Saham, Ekonomi, Keuangan dan Investasi )}

Vol.1, No.4, Juni 2018

Halaman : 92 - 105

C LPPM \& Prodi Manajemen

UNIVERSITAS PAMULANG

ISSN (online) : 2581-2777

ISSN (print) : :2581-2696

\section{Keyword :}

Profitabilitas, Ukuran

perusahaan, Tangibility,

Pertumbuhan Perusahaan,

Struktur Modal.

JEL. classification :

C33, G20, G23, N65

\section{Contact Author :}

PRODI MANAJEMEN UNPAM

JL.Surya Kencana No.1 Pamulang

Tangerang Selatan - Banten

Telp. (021) 7412566, Fax (021) 7412491

Email :

jurnalfinance.unpam@gmail.com

\section{ABSTRACT}




\section{A. Pendahuluan}

Salah satu keputusan keuangan yang patut menjadi perhatian utama oleh manajer perusahaan adalah keputusan sumber pendanaan atau yang lebih dikenal dengan struktur modal. Keputusan dalam struktur modal semakin diperlukan khususnya dalam kondisi krisis global seperti sekarang ini, dimana capital outflow lebih banyak dibandingkan capital inflow sehingga biaya modal menjadi mahal. Krisis keuangan yang terjadi di beberapa negara telah berkembang menjadi masalah serius. Gejolak tersebut mulai mempengaruhi stabilitas ekonomi global di beberapa kawasan. Hampir semua negara di dunia menganut sistem pasar bebas sehingga terkait satu sama lain. Aliran dana bebas keluar masuk dari satu negara ke negara lain dengan regulasi moneter tiap negara yang beragam. Krisis global ini menyebabkan larinya modal dari tempat yang kurang aman menuju yang dianggap lebih aman.Salah satu peneliti yang menguji tentang struktur modal yaitu Caglayan dan Sak (2010), dimana terdapat beberapa faktor yang mempengaruhi struktur modal yaitu faktor profitability, size, tangibility, growth, gross domestic product, dan capital market. Hubungan profit dengan struktur modal secara pecking order theory berhubungan negatif, dimana semakin tinggi profit maka akan semakin rendah tingkat hutang perusahaan karena perusahaan pada prinsipnya akan menggunakan sumber modal yang menimbulkan biaya bunga paling rendah dalam hal ini adalah menggunakan laba ditahan sebagai sumber modal. Jika profit berhubungan negatif dengan struktur modal, hal sebaliknya berbeda dengan tangibility dan growth opportunity berhubungan positif dengan struktur modal.

Selain faktor internal perusahaan yang mempengaruhi struktur modal, faktor eksternal atau yang dikenal dengan faktor makro juga mempengaruhi struktur modal, seperti yang ditemukan oleh Booth et.al. (2001) bahwa faktor makro seperti GDP, inflasi, dan nilai kapitalisasi pasar modal berpengaruh terhadap struktur modal perusahaan. Semakin baik pertumbuhan pasar modal di suatu negara maka akan semakin mudah akses bagi perusahaan untuk mendapatkan sumber pendanaan dengan menerbitkan saham sehingga tingkat hutang menjadi berkurang, dan kondisi inflasi yang tinggi akan menyebabkan tingkat suku bungan penjaman menjadi tinggi sehingga pelaku usaha akan menghindari hutang, hal ini akan mempengaruhi struktur modal perusahaan. Berdasarkan latar belakang pemikiran di atas, dilakukan penelitian dengan judul "Pengaruh Profitabilitas, Size, Tangibility, dan Pertumbuhan Terhadap Struktur Modal Pada Perbankan Yang Terdaftar Di BEI Periode 2008-2016".

\section{B. Perumusan Masalah}

Berdasarkan latar belakang masalah tersebut, maka dapat dibuat perumusan masalah dalam penelitian ini sebagai berikut:

1. Apakah profitabilitas berpengaruh terhadap struktur modal pada Bank yang terdaftar di BEI periode 2008-2016 ?

2. Apakah size berpengaruh terhadap struktur modal pada Bank yang terdaftar di BEl periode 2008-2016?

3. Apakah tangibility berpengaruh terhadap struktur modal pada Bank yang terdaftar di BEI periode 2008-2016?

4. Apakah pertumbuhan berpengaruh terhadap struktur modal pada Bank yang terdaftar di BEI periode 2008-2011?

4. Apakah profitabilitas, size, tangibility, dan pertumbuhan berpengaruh secara simultan terhadap struktur modal pada Bank yang terdaftar di BEI periode 2008$2016 ?$ 


\section{Tujuan Penelitian}

1. Menganalisis pengaruh profitabilitas terhadap struktur modal pada Bank yang terdaftar di BEl periode 2008-2016.

2. Menganalisis pengaruh size terhadap struktur modal pada Bank yang terdaftar di BEl periode 2008-2016.

3. Menganalisis pengaruh tangibility terhadap struktur modal pada Bank yang terdaftar di BEl periode 2008-2016.

4. Menganalisis pengaruh pertumbuhan terhadap struktur modal pada Bank yang terdaftar di BEl periode 2008-2011.

5. Menganalisis pengaruh profitabilitas, size, tangibility, dan pertumbuhan secara simultan terhadap struktur modal pada Bank yang terdaftar di BEI periode 2008-2016

\section{Landasan Teori}

\section{Struktur Modal}

Struktur modal secara garis besar terdiri dari kewajiban-kewajiban perusahaan yang harus dibayarkan (liability) atau dapat disebut sebagai hutang perusahaan serta ekuitas atau modal sendiri (Karadeniz et al., 2009:594). Leverage keuangan adalah indikator penting untuk menentukan struktur modal yang optimal bagi perusahaan dimana sejumlah penelitian empiris telah mengidentifikasi beberapa karakteristik yang mempengaruhi struktur modal perusahaan (Caglayan dan Sak, 2010).

Leverage terkait dengan hutang, Hutang (debt) merupakan kewajiban keuangan kepada pihak lain, selain kepada pemilik. Hutang dapat berupa hutang usaha terhadap perorangan atau badan usaha (Sundjaja dan Barlian, 2007). Kemampuan perusahaan untuk membayar biaya tetap diukur dengan menggunakan rasio mampu. Rasio mampu yang tinggi lebih disukai, tetapi terlalu tinggi rasio tersebut (di atas rata-rata industri) menunjukan adanya kewajiban tetap yang tidak digunakan dengan baik. Sebaliknya semakin rendah rasio mampu maka perusahaan lebih beresiko untuk tidak dapat membayar kewajiban tetapnya.

\section{Profitabilitas}

$$
\mathrm{DER}=\frac{\text { Total Hutang }}{\text { Total Ekuitas }}
$$

Profitabilitas adalah hasil akhir dari sejumlah kebijakan dan keputusan yang dilakukan oleh perusahaan. Rasio profitabilitas (profitability ratio) akan menunjukkan kombinasi efek dari likuiditas, manajemen aktiva, dan utang pada hasil-hasil operasi.Profitabilitas didefinisikan sebagai rasio laba sebelum bunga, pajak dan penyusutan terhadap jumlah aktiva (Dessomsak et.al., 2004). Teori pecking-order mendalilkan bahwa manajer lebih memilih untuk membiayai proyek-proyek internal karena adanya asimetri informasi antara manajer dan investor luar. Selain itu, perusahaan dengan profitabilitas yang tinggi memilih untuk tidak menaikkan ekuitas eksternal untuk menghindari potensi dilusi kepemilikan. Jadi, ada hubungan terbalik antara profitabilitas dan leverage.

Terdapat hubungan antara kemampuan memperoleh keuntungan (profitability) dengan rasio hutang dalam pecking order theory dan trade-offtheory. Dalam peckingordertheory, cenderung berhubungan negatif (profitabilitas terhadap rasio hutang), sementara trade-offtheory cenderung berhubungan positif antara profitabilitas terhadap rasio hutang (Benito, 2003; Krasker, 1986; Myers, 1984; Myers dan Majluf,1984 dalam Kardeniz et.al., 2009:597).

$$
\mathrm{ROE}=\frac{\text { Laba Bersih }}{\text { Total Ekuitas }}
$$




\section{Ukuran Perusahaan}

Ukuran (size) perusahaan ditentukan oleh struktur modal yang dimiliki oleh perusahaan. Ukuran perusahaan menunjukkan tidak banyak berpengaruh pada hutang keuangan perusahaan, hal ini berdasarkan hasil penelitian menggunakan trade off theory dan pecking order theory yang dilakukan oleh Cassar dan Holmes (2003) dalam Afza dan Hussain (2011:221).Titman dan Wessels (1988) dalam Abor dan Biekpe (2007:86) menyebutkan, perusahaan berukuran kecil cenderung memiliki hutang jangka pendek dibandingkan dengan perusahaan berukuran besar.

Dessomsak et.al., (2004) menyatakan tangibility didefinisikan sebagai rasio aktiva tetap terhadap jumlah aktiva. Karadeniz et al. (2009:597) menyebutkan bahwa trade-off theory berhubungan positif antara tangibility dengan rasio hutang. Almeida dan Campello (2007) dalam Kayo dan Kimura (2010:360) menyebutkan bahwa tangibility merupakan faktor penting dalam membatasi keuangan perusahaan, sehingga memberikan batasan dalam menggunakan sumber pendanaan dari luar. Bagaimanapun juga, tangibility tidak menjadi penting ketika perusahaan tidak memberikan batasan penggunaanya.

$$
\text { Tangibility }=\frac{\text { Aset Tetap }}{\text { Total Aset }}
$$

\section{Pertumbuhan Perusahaan}

Pihak manajemen yang menginginkan pertumbuhan (growth), ekuitas external perusahaan yang dimiliki lebih bernilai dibandingkan kesempatan investasi yang besar (Jung, Kim, dan Stulz dalam Parlak, 2010:149)dalam penelitian Smith dan Watts (1992) dalam Parlak (2010:149) menemukan bahwa terjadi hubungan yang negatif antara leverage dengan pertumbuhan. Pertumbuhan merupakan faktor penting dalam mempengaruhi rasio ekuitas hutang pada perusahaan berdasarkan hasil analisis regresis dengan menggunakan trade off theory dan pecking order theory (Cassar dan Holmes, 2003 dalam Afza dan Hussain, 2011:221).

\section{Kerangka Pemikiran}

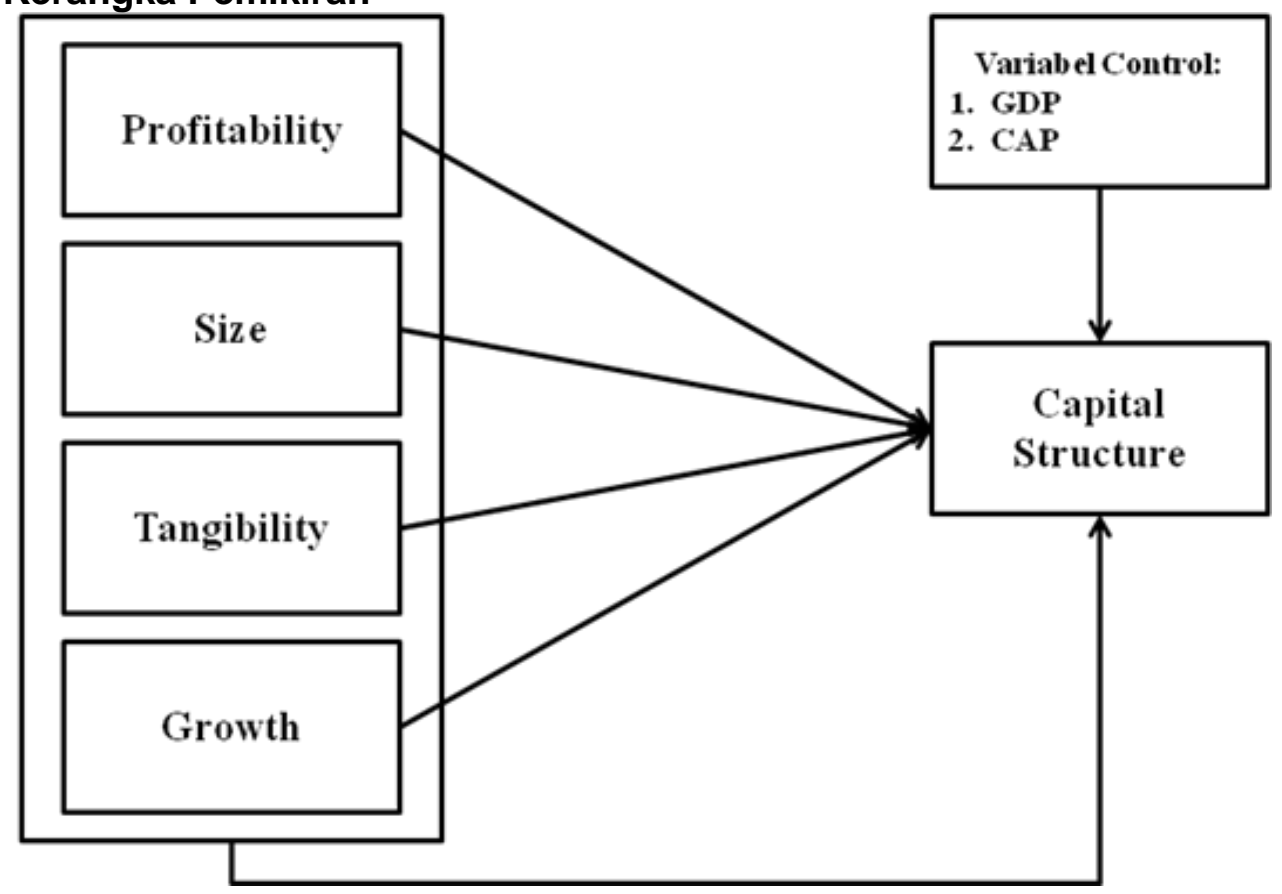




\section{E. Hubungan Antar Variabel}

Perusahaan untuk tumbuh dan berkembang memerlukan modal atau sumber dana yang akan digunakan dalam membiayai kegiatan bisnisnya. Oleh sebab itu, perusahaan harus dapat menentukan struktur modal yang optimal sehingga nilai perusahaan meningkat. Ada beberapa faktor yang mempengaruhi struktur modal. Berdasarkan Psillaki dan Daskalakis faktor- faktor yang mempengaruhi capital structure adalah profitabilitas, ukuran perusahaan, tangibilitydan pertumbuhan perusahaan risk (Psillaki dan Daskalakis, 2008).

Profitabilitas merupakan tingkat laba yang dihasilkan oleh aktivitas perusahaan. Dalam penelitian ini profitabilitas dapat diukur dengan cara membandingkan EBIT dengan total ekuitas perusahaan.Perusahaan dengan tingkat pengembalian yang tinggi cenderung menggunakan proporsi hutang yang relatif kecil, karena dengan tingkat pengembalian yang tinggi, kebutuhan pendanaan dapat diperoleh dari keuntungan yang ditahan Hermuningsih (2013). Perusahaan dengan profitabilitas tinggi akan memiliki dana internal lebih banyak daripada yang memiliki tingkat profitabilitas rendah. Jika dalam komposisi struktur modal, penggunaan modal sendiri lebih banyak daripada penggunaan hutang, maka rasio struktur modal akan lebih kecil. Dengan demikian, berdasarkan teori di atas, tingkat profitabilitas yang lebih tinggi, rasio struktur modal yang lebih rendah dan menyatakan bahwa profitabilitas berpengaruh negatif terhadap struktur modal.Profitability mempunyai pengaruh yang negatif terhadap struktur modal. Jika profitability suatu perusahaan mengalami peningkatan maka struktur modal perusahaan akan menurun, perusahaan dengan tingkat profitability yang tinggi akan menggunakan hutang yang lebih kecil karena perusahaan mampu menyediakan dana yang cukup melalui laba ditahan. Berdasarkan teori tersebut maka hipotesis dalam penelitian ini adalah:

Ha1 : Profitabilitas berpengaruh signifikan terhadap struktur modal pada Bank yang terdaftar di BEl periode 2008-2016 dikontrol oleh variabel GDP dan capital market.

Ukuran perusahaan adalah besarnya perusahaan yang dapat diukur dengan menggunakan total penjulan. Dalam penelitian ini, variabel ukuran perusahaan diukur dengan menggunakan nilai logaritma dari total penjualan.Abor dan Biekpe (2007:86) berpendapat bahwa, perusahaan berukuran besar juga memiliki leverage yang lebih besar dikarenakan biaya kebangkrutan pada hutang lebih kecil bagi perusahaan besar.Ukuran perusahaan dapat diukur dengan melakukan natural logaritmh of total sales. Firm size dapat dikaitkan dengan fleksibilitas dalam pendanaannya.

Perusahaan yang berskala kecil akan menemukan kesulitan-kesulitan yang diantaranya perusahaan tersebut akan membutuhkan biaya transaksi yang lebih untuk berhubungan dengan para pemberi pinjaman. Firm size berhubungan positif terhadap struktur modal sebab perusahaan yang besar cenderung mempunyai reputasi yang baik dan memiliki informasi perusahaan yang lebih spesifikasi artinya perusahaan yang besar lebih mudah untuk mendapatkan pendanaan dari hutang (Cassar dan Holmes, 2004).Berdasarkan teori tersebut maka hipotesis dalam penelitian ini adalah:

$\mathrm{Ha} 2$ : Size berpengaruh signifikan terhadap struktur modal pada Bank yang terdaftar di BEI periode 2008-2016 dikontrol oleh variabel GDP dan capital market.

Afza dan Hussain juga membuktikan bahwa tangibility assets juga terbukti mempengaruhi struktur modal pada sektor otomotif di Pakistan (Afza dan Hussain, 2011).Faktor tangibility berperan penting dalam struktur modal, dimana hal ini sebagai aspek jaminan pada asset untuk meningkatkan leverage. Karena itu terdapat hubungan yang positif antara tangibility dengan leverage (Kayo dan Kimura, 2010:360).Berdasarkan teori tersebut maka hipotesis dalam penelitian ini adalah: 
Ha3 : Tangibility berpengaruh signifikan terhadap struktur modal pada Bank yang terdaftar di BEI periode 2008-2016 dikontrol oleh variabel GDP dan capital market.

Peluang pertumbuhan adalah peluang pertumbuhan perusahaan di masa depan (Mai, 2006). Peluang pertumbuhan adalah ukuran seberapa jauh laba per saham perusahaan dapat ditingkatkan dengan leverage. Perusahaan dengan pertumbuhan yang cepat beberapa kali harus meningkatkan aset tetapnya. Oleh karena itu, perusahaan dengan pertumbuhan yang cepat membutuhkan lebih banyak dana di masa depan dan lebih banyak laba ditahan. Saldo laba dari perusahaan dengan pertumbuhan yang cepat akan meningkat dan perusahaan-perusahaan tersebut akan berurusan lebih banyak dengan hutang untuk mempertahankan rasio ekuitas yang ditargetkan (Mai, 2006).Pertumbuhan penjualan merupakan potensi perusahaan untuk tumbuh dan berkembangan dengan hasil penjualannya. Growth (pertumbuhan penjualan) diukur dengan percentage growth in sales yaitu membandingkan antara penjualan tahun yang bersangkutan dengan penjualan tahun sebelumnya.Menurut Cassar dan Holmes (2004) growth berpengaruh positif terhadap struktur modal. Perusahaan dengan tingkat pertumbuhan yang semakin tinggi maka semakin tinggi juga keinginan perusahaan tersebut untuk menahan laba dan menggunakan hutang untuk biaya ekspansi.

Ha4 : Pertumbuhan perusahaan berpengaruh signifikan terhadap struktur modal pada Bank yang terdaftar di BEI periode 2008-2016 dikontrol oleh variabel GDP dan capital market.

Ha5 : Profitabilitas, size, tangibility, dan pertumbuhan perusahaan secara simultan berpengaruh signifikan terhadap struktur modal pada Bank yang terdaftar di BEl periode 2008-2016 dikontrol oleh variabel GDP dan capital market.

\section{F. Metodologi}

Penelitian ini bertujuan untuk menguji apakah terdapat pengaruh profitabilitas, size, tangibility, dan pertumbuhan perusahaan terhadap struktur modal pada Bank yang terdaftar di BEl periode 2008-2016 dikontrol oleh variabel GDP dan capital market. Perusahaan yang menjadi objek dalam penelitian ini adalah perusahaan perbankan yang terdaftar di BEl periode 2008-2016 dengan sampel sebanyak 17 perusahaan perbankan. Jenis data yang digunakan dalam penelitian ini terdiri dari data sekunder, berupa data laporan keuangan. Data sekunder dalam penelitian ini bersumber dari Bursa Efek Indonesiaperiode 2008-2016.Adapun teknik analisis yang dilakukan yaitu menggunakan data panel, sedangkan pengolahan data menggunakan EViews 8. Data panel merupakan gabungan antara data time series dan cross section.

\section{G. Hasil dan Pembahasan}

Sebelum dilakukannya pengujian regresi berganda dan Hipotesis. Peneliti lebih dahulu melakukan pengujian asumsi klasik. Berikut hasil pengujian asumsi klasik dalam penelitian ini:

\section{Uji Asumsi Klasik \\ Uji Normalitas}

Hasil pengujian normalitas dapat dilihat pada tabel berikut ini:

Tabel 1. Hasil Uji Normalitas 


\begin{tabular}{|lr|}
\hline Series: Residuals \\
Sample 1 153 \\
bbservations 153 \\
Mean & $5.42 \mathrm{e}-14$ \\
Median & 0.155578 \\
Maxmum & 8.305997 \\
Minimum & -12.74681 \\
Std. Dev. & 2.936187 \\
Skewmess & -0.498002 \\
Kurtosis & 5.416189 \\
Jarque-Eera & 43.54120 \\
Probability & 0.078012 \\
\hline
\end{tabular}

Hasil uji normalitas dengan Jarque-Beramenujukkan bahwa uji normalitas terpenuhi karena nilai signifikan yang diperoleh lebih besar dari 0,05 artinya data telah berdistribusi secara normal.

\section{Uji Multikolinearitas}

Hasil pengujian multikolinearitas pada penelitian ini dapat dilihat pada tabel berikut ini:

Tabel 2. Hasil Uji Multikolinearitas

\begin{tabular}{|c|c|c|c|}
\hline Variable & $\begin{array}{l}\text { Coefficient } \\
\text { Variance }\end{array}$ & $\begin{array}{c}\text { Uncentered } \\
\text { VIF }\end{array}$ & $\begin{array}{l}\text { Centered } \\
\text { VIF }\end{array}$ \\
\hline C & 888.9378 & 15153.21 & NA \\
\hline ROE & 0.953964 & 1.373778 & 1.139190 \\
\hline SIZE & 0.057481 & 287.2907 & 2.787972 \\
\hline TANG & 183.4771 & 2.584674 & 1.131782 \\
\hline GROWTH & 0.025356 & 1.082014 & 1.028405 \\
\hline CAP & 0.029812 & 419.1816 & 2.469577 \\
\hline GDP & 1.812125 & 15950.15 & 1.201438 \\
\hline
\end{tabular}

Hasil uji multikolinearitas menunjukkan bahwa antara profitabilitas (ROE), ukuran perusahaan (SIZE), tangibility (TANG) dan pertumbuhan perusahaan (GROWTH) tidak saling berkolerasi atau tidak terjadi multikolinearitas pada model regresi karena memperoleh nilai Centered VIF $<10$.

\section{Uji Multikolinearitas}

Hasil pengujian heteroskedasititas pada penelitian ini dapat dilihat pada tabel berikut ini:

Tabel 3. Hasil Uji Heteroskedastisitas

Heteroskedasticity Test: White

\begin{tabular}{llll}
\hline \hline F-statistic & 28.12207 & Prob. F(6,146) & 0.0000 \\
Obs*R-squared & 82.02543 & Prob. Chi-Square(6) & 0.0000 \\
Scaled explained SS & 164.9259 & Prob. Chi-Square(6) & 0.0000 \\
\hline
\end{tabular}

Hasil uji heteroskedasititas menunjukkan bahwa keempat variabel yaitu profitabilitas(ROE), ukuran perusahaan (SIZE), tangibility (TANG) dan pertumbuhan perusahaan (GROWTH) terjadi heteroskedasititas, karena pada memiliki nilai signifikan $\mathrm{Obs}^{*} \mathrm{R}$-squared $<0,05$. 


\section{Uji Autokorelasi}

Hasil pengujian autokorelasi pada penelitian ini dapat dilihat pada tabel berikut ini:

Tabel 4. Hasil Uji Autokorelasi

Breusch-Godfrey Serial Correlation LM Test:

\begin{tabular}{llll}
\hline \hline F-statistic & 20.28256 & Prob. F(2,144) & 0.0000 \\
Obs $^{\star}$ R-squared & 33.62750 & Prob. Chi-Square(2) & 0.0000 \\
\hline \hline
\end{tabular}

Hasil uji autokorelasi menunjukkan bahwa data pengamatan dalam penelitian ini memiliki autokorelasi. Hal tersebut ditunjukkan dengan perolehan nilai signifikan Obs* R-squared sebesar $0,000<$ dari 0,05 .

Selanjutnya, uji pemilihan model regresi data panel dalam penelitian ini dilakukan dengan chow-test, hausman-test, dan LM-test sebagai berikut:

\section{Pemilihan Model terbaik}

Tabel 5. Hasil Chow-Test

Redundant Fixed Effects Tests

Equation: Untitled

Test cross-section fixed effects

\begin{tabular}{lrrr}
\hline \hline Effects Test & Statistic & d.f. & Prob. \\
\hline \hline Cross-section F & 2.507583 & $(16,130)$ & 0.0022 \\
Cross-section Chi-square & 41.153549 & 16 & 0.0005 \\
\hline
\end{tabular}

Hasil dari tabel 5tersebut menunjukkan baik $\mathrm{F}$ test maupun Chi-Square signifikan (p-value 0,000 lebih kecil dari 5\%) sehingga berdasarkan hasil chow-test model yang baik mengikuti Fixed Effect Model (FEM). Dengan kata lain, Fixed Effect Model lebih baik daripada model Common Effect Model.

Tabel 6. Hasil Hausman Test

Correlated Random Effects - Hausman Test

Equation: Untitled

Test cross-section random effects

\begin{tabular}{llrl}
\hline \hline Test Summary & $\begin{array}{l}\text { Chi-Sq. } \\
\text { Statistic }\end{array}$ & Chi-Sq. d.f. & Prob. \\
\hline \hline Cross-section random & 8.385471 & 6 & 0.2112
\end{tabular}

Hasil uji Hausman-test tabel 6, dapat dilihat bahwa nilai p-value $(0,2112)>$ alpha $(0,05)$. Dengan demikian, berdasarkan uji hausman pendekatan estimasi model mengikuti Random Effect Model (REM). Dengan kata lain, Random Effect Model lebih baik daripada model Fixed Effect Model.

Tabel 7. Hasil LM-Test

Breusch-Godfrey Serial Correlation LM Test:

\begin{tabular}{llll}
\hline \hline F-statistic & 20.28256 & Prob. F(2,144) & 0.0000 \\
Obs ${ }^{*}$ R-squared & 33.62750 & Prob. Chi-Square(2) & 0.0000 \\
\hline
\end{tabular}

Berdasarkan hasil uji LM diketahui bahwa nilai $O b{ }^{*} R$-squareBreusch-Godfrey SerialCorrelation LM Test yaitu sebesar 33.62750 lebih besar dari nilai chi-square 
tabel sebesar 12,591. Dengan demikian, berdasarkan uji LM pendekatan estimasi model mengikuti RandomEffect Model (REM). Dengan kata lain, Random Effect Model lebih baik daripada model Common Effect Model.

Berdasarkan hasil ketiga uji pemilihan model regresi data panel yang sudah dilakukan, didapat hasil yang berbeda disetiap ujinya. Berdsarkan hasil uji terebut model estimasi data panel yang yang baik untuk digunakan pada data penelitian ini adalah Random Effect Model (REM).

\section{Analsisi Regresi Berganda}

Uji regresi data panel dalam penelitian ini menggunakan Random Effect Model (REM). Namun demikian, karena hasil uji asumsi klasik data dalam penelitian ini mengalami masalah heteroskedastisitas dan autokorelasi maka dalam estimasi Random Effect Model menggunakan Cross-Section SUR (PCSE) untuk menanggulangi masalah asumsi klasik tersebut. Hasil disajikan pada Tabel 10 berikut ini.

Tabel 8. Hasil Uji Regresi Data Panel

\begin{tabular}{lrrccc}
\hline & Coefficient & $\begin{array}{c}\text { t- } \\
\text { Statistics }\end{array}$ & Sig. & $\begin{array}{c}\text { Adj. R- } \\
\text { Squared }\end{array}$ & F-statistics \\
\hline C & 178,8200 & 5,4735 & 0,0000 & & \\
ROE & $-11,1499$ & $-5,8723$ & 0,0000 & & \\
SIZE & 0,8459 & 3,0921 & 0,0024 & & 32,190 \\
TANG & $-66,8670$ & $-3,6541$ & 0,0004 & 0,552 & $(0,000)$ \\
GROWTH & 0,0141 & 0,1329 & 0,8945 & & \\
CAP & $-0,2778$ & $-1,6226$ & 0,1068 & & \\
GDP & $-7,6716$ & $-5,1971$ & 0,0000 & & \\
\hline
\end{tabular}

Berdasarkan output pengujian diatas, maka dapat dibuatkan persamaan regresi sebagai berikut:

\section{DER $=178,8200-11,1499 \mathrm{ROE}+0,8459 \mathrm{SIZE}-66,8670$ TANG +} 0,0141GROWTH - 0,2778CAP - 7,6716 + e

Hasil persamaan regresi terhadap signifikasi koefisien dan interprestasi dari persamaan regresi tersebut adalah sebagai berikut:

Hasil pengujian pada Tabel 10, menginformasikan bahwa profitabilitas (ROE), ukuran perusahaan (SIZE), dan tangibility (TANG) secara parsial berpengaruh signifikan terhadap struktur modal yang diproksikan dengan DER. Hasil ini juga menunjukkan bahwa variabel tangibility (TANG) merupakan variabel yang paling dominan pengaruhnya terhadap struktur modal perusahaan, hal ini didukung dengan perolehan koefisien beta sebesar 66,87 lebih besar dari variabel ROE, SIZE, dan GROWTH. Sementara itu, pertumbuhan perusahaan (GROWTH )merupakan variabel yang pengaruhnya paling kecil terhadap struktur modal perusahaan yaitu sebesar 0,278.

\section{Analsisi Hipotesis}

Pengujian ini dilakukan untuk menguji apakah terdapat pengaruh profitability, ukurang perusahaan, tangibility, dan pertumbuhan perusahaan terhadap struktur modal perusahaan dengan dikontrol oleh variabel Gross Domestic Product(GDP) dan Capital Market(CAP). Uji Hipotesa ini dibagi menjadi tiga bagian sebagai berikut:

Dasar pengambilan keputusan berdasarkan nilai signifikansi, jika nilai signifikan lebih kecil dari tingkat kesalahan 5\% (sig. < 0,05) maka Ho ditolak. Hasil pengujian tersebut secara ringkas dapat dilihat pada Tabel 8 berikut ini.

Tabel 9. Hasil Uji Hipotesis Parsial (Uji t) 


\begin{tabular}{lrl}
\hline Variabel & t-Statistics & Sig. \\
\hline ROE & $-5,8723$ & 0,0000 \\
SIZE & 3,0921 & 0,0024 \\
TANG & $-3,6541$ & 0,0004 \\
GROWTH & 0,1329 & 0,8945 \\
CAP & $-1,6226$ & 0,1068 \\
GDP & $-5,1971$ & 0,0000 \\
\hline
\end{tabular}

Berdasarkan Tabel 9 dapat dijelaskan mengenai hasil hipotesis uji t.Hipotesis pertama menguji adanya pengaruh profitabilitas terhadap struktur modal perusahaan pada perusahaan perbankan yang terdaftardi Bursa Efek Indonesia periode 2008-2016. Hipotesis yang diajukkan sebagai berikut.

Ho1 = Profitabilitas tidak berpengaruh signifikan terhadap struktur modal perusahaan

Ha1 = Profitabilitas berpengaruh signifikan terhadap struktur modal perusahaan

Melihat Tabel 9 hasil hipotesis variabel profitabilitas (ROE) terhadap struktur modal perusahaan (DER) menghasilkan nilai $t$ hitung sebesar $-5,8723>t$ tabel $1,976(\mathrm{df}=146$, alpha=0,05)dan nilai signifikan sebesar $0,000<$ alpha 0,05 . Dengan demikian, Ho1 ditolak dan Ha1 diterima, sehingga dapat disimpulkan bahwa profitabilitas (ROE) berpengaruh signifikan terhadap struktur modal perbankan yang terdaftardi Bursa Efek Indonesia periode 2008-2016.

Hipotesis kedua menguji adanya pengaruh ukuran perusahaan (SIZE) terhadap struktur modal perusahaan pada perusahaan perbankan yang terdaftardi Bursa Efek Indonesia periode 2008-2016. Hipotesis yang diajukkan sebagai berikut.

Ho2 = Size tidak berpengaruh signifikan terhadap struktur modal perusahaan

Ha2 = Size berpengaruh signifikan terhadap struktur modal perusahaan

Melihat Tabel 9 hasil hipotesis variabel ukuran perusahaan (SIZE) terhadap struktur modal perusahaan (DER) menghasilkan nilai t hitung sebesar 3.0921 > $t$ tabel 1,976 ( $\mathrm{df}=146$, alpha=0,05) dan nilai signifikan sebesar 0,002 < alpha 0,05. Dengan demikian, Ho2 ditolak dan Ha2 diterima, sehingga dapat disimpulkan bahwa ukuran perusahaan (SIZE)berpengaruh signifikan terhadap struktur modal perbankan yang terdaftardi Bursa Efek Indonesia periode 2008-2016.

Hipotesis ketiga menguji adanya pengaruh tangibility (TANG) terhadap struktur modal perusahaan pada perusahaan perbankan yang terdaftardi Bursa Efek Indonesia periode 2008-2016. Hipotesis yang diajukkan sebagai berikut.

Ho3 = Tangibilitytidak berpengaruh signifikan terhadap struktur modal perusahaan

Ha3 = Tangibilityberpengaruh signifikan terhadap struktur modal perusahaan

Melihat Tabel 9 hasil hipotesis variabel tangibility (TANG) terhadap struktur modal perusahaan (DER) menghasilkan nilai $t$ hitung sebesar $-3.6541>t$ tabel $1,976(\mathrm{df}=146$, alpha=0,05) dan nilai signifikan sebesar $0,000<$ alpha 0,05 . Dengan demikian, Ho3 ditolak dan Ha3 diterima, sehingga dapat disimpulkan bahwa tangibility (TANG) berpengaruh signifikan terhadap struktur modal perbankan yang terdaftardi Bursa Efek Indonesia periode 2008-2016.

Hipotesis keempat menguji adanya pengaruh pertumbuhan perusahaan (GROWTH) terhadap struktur modal perusahaan pada perusahaan perbankan yang terdaftardi Bursa Efek Indonesia periode 2008-2016. Hipotesis yang diajukkan sebagai berikut. 
Ho4 = Pertumbuhan perusahaantidak berpengaruh signifikan terhadap struktur modal perusahaan

$\mathrm{Ha} 4$ = Pertumbuhan perusahaanberpengaruh signifikan terhadap struktur modal perusahaan

Melihat Tabel 9 hasil hipotesis variabel pertumbuhan perusahaan (GROWTH) terhadap struktur modal perusahaan (DER) menghasilkan nilai $t$ hitung sebesar $0,1329<\mathrm{t}$ tabel 1,976 $(\mathrm{df}=146$, alpha=0,05)dan nilai signifikan sebesar 0,8945 > alpha 0,05. Dengan demikian, Ho4 diterima dan Ha4ditolak, sehingga dapat disimpulkan bahwa pertumbuhan perusahaan (GROWTH) tidak berpengaruh signifikan terhadap struktur modal perbankan yang terdaftar di Bursa Efek Indonesia periode 2008-2016.

Tabel 10. Hasil Hipotesis Simultan (Uji F)

\begin{tabular}{|c|c|}
\hline F-statistik & Sig. \\
\hline 32,190 & 0,000 \\
\hline
\end{tabular}

Hasil uji simultan atau Uji F digunakan untuk menguji apakah secara bersama-sama seluruh variabel independen memiliki pengaruh terhadap variabel dependen. Dasar pengambilan keputusan berdasarkan nilai signifikansi, jika nilai $F$ hitung lebih besar dari $\mathrm{F}$ tabel atau signifikan lebih kecil dari tingkat kesalahan 5\% (sig. < 0,05) maka Ho ditolak.

Hipotesis yang diajukkan dalam hal ini adalah sebagai berikut.

$\mathrm{Ho5}=$ Profitabilitas, ukuran perusahaan, tangibility, dan pertumbuhan perusahaan tidak berpengaruh signifikan terhadap struktur modal perusahaan

Ha5 = Profitabilitas, ukuran perusahaan, tangibility, dan pertumbuhan perusahaan tidak berpengaruh signifikan terhadap struktur modal perusahaan

Melihat Tabel 10 di atas, hasil uji hipotesis simultan atau uji $\mathrm{F}$ menghasilkan nilai $\mathrm{F}$ hitung sebesar 32,190> Ftabel $(2,161)$ dan nilai signifikan sebesar 0,000 lebih kecil dari 0,05. Dengan demikian, Ho5 ditolak dan Ha5 diterima. Artinya variabel Profitabilitas, ukuran perusahaan, tangibility, dan pertumbuhan perusahaan tidak berpengaruh signifikan terhadap struktur modal perbankan yang terdaftar di Bursa Efek Indonesia periode 2008-2016.

Berdasarkan hasil pengujian koefisien determinasi diperoleh nilai Adjusted RSquare sebesar 0,552 atau sebesar $55,2 \%$. Artinya variabel profitabilitas, ukuran perusahaan, tangibility, dan pertumbuhan perusahaan secara bersama-sama memberikan pengaruh sebesar $55,2 \%$ terhadap struktur modal perusahaan perbankan yang terdaftar di Bursa Efek Indonesia periode 2008-2016. Sedangkan sisanya $44,8 \%$ dipengaruhi oleh variabel lain diluar model penelitian.

\section{H. Pembahasan Penelitian}

\section{Profitabilitas Terhadap Struktur Modal}

Profitabilitas berefek negatif serta signifikan terhadap struktur modal. Halini memberikan arti bahwa semakin tinggi kemampuan perusahaan memperolehprofit, maka dengan demikian semakin tinggi pula kemampuan perusahaantersebut untuk dapat membiayai investasi yang dilakukannya dengan dana internalyang dimiliki seperti laba ditahan. Hasil penelitian ini mendukung hasil penelitiansebelumnya yang dilakukan oleh Joni dan Lina (2010), Cekrezi (2013) dan Alom(2013) yang menemukan bahwa profitabilitas berpengaruh negatif terhadapstruktur modal perusahaan 


\section{Pengaruh Inflasi terhadap harga Obligasi}

Ukuran perusahaan berefek positif serta signifikan terhadap strukturmodal. Berarti perusahaan yang besar akan lebih mudah mendapatkan investoryang akan menanamkan modalnya serta dalam hal memperoleh kreditdibandingkan dengan perusahaan yang berskala yang lebih kecil. Hasil penelitianini mendukung hasil penelitian sebelumnya yang dilakukan oleh Momami et.al.(2010), Owolabi and Inyang (2012), dan Karadeniz et al. (2011) yang menemukan hasil bahwa ukuran perusahaan berefek positif dan signifikan terhadap struktur modal. Penelitian yang dilakukan oleh Widodo et.al. (2014) juga menemukan adanya pengaruh signifikan ukuran perusahaanberpengaruh terhadap struktur modal perusahaan.Ukuran suatu perusahaan dapat digunakan sebagai gambaran sebagianjumlah asset yang dapat dijadikan jaminan. Dengan kata lain, semakin besar ukuran perusahaan,biaya penerbitan ekuitas menjadi lebih murah.

\section{Tangibility Terhadap Struktur Modal}

Hasil penelitian ini mendukung hasil dari penelitiansebelumnya yang dilakukan oleh Liem et.al. (2013), Indrajaya et.al. (2011), danMomami et al. (2010) yang menemukan hasil bahwa tangibility assetsberpengaruh terhadap struktur modal.Tangibility berpengaruh positif dan signifikanterhadap struktur modal perusahaan. Yang denganmembaiknya tangibility akan mampu memperbaikistruktur modal perusahaan. Hasil penelitian ini sesuai denganpenelitian yang dilakukan Serrasqueiro dan Rogao (2009), Omran (2009), Amidu (2007), Titman danWessels (1988), Seppa (2007), Zhang dan Kanazaki(2007). Hal inisesuai dengan teori trade off yang menyatakan bahwaperusahaan dengan tangibility yang besar dapatdijaminkan yang dapat menurunkan resikopemberi pinjaman ketika memberikan hutang.Ketika perusahaan mempunyai jaminan yang tinggi,maka akan lebih mudah memperoleh pinjaman kreditdalam jumlah yang lebih besar pula.

\section{Pertumbuhan Perusahaan Terhadap Struktur Modal}

Peluang pertumbuhan memiliki pengaruh positif dan namun tidak signifikan terhadap struktur modal. Hasil uji menunjukkan nilai sign. sebesar 0,8945> 0,05. Hasil penelitian ini sejalan dengan temuan penelitian yang dilakukan oleh Widodo et.al (2014) bahwa pertumbuhan tidak berpengaruh signifikan terhadapstruktur modal perusahaan. Nilai koefisien yang menunjukkan positif sejalan dengan hasil penelitian Hermuningsih (2013) bahwa terdapat hubungan positif pertumbungan perusahaan dengan struktur modal. Pertumbuhanpenjualan akan mempengaruhi perubahan struktur modal. Nilai keofisien regresibernilai positif ini menunjukkan bahwa meningkatnya pertumbuhan penjualanakan diikuti dengan meningkatnya struktur modal dan sebaliknya. Pertumbuhanpenjualan yang tinggi akan menjadi salah satu pertimbangan bagi perusahaandalam menentukan besarnya jumlah hutang yang akan digunakan.

\section{Kesimpulan}

1. Profitabilitas yang diproksikan dengan return on equity (ROE) terbukti memiliki pengaruh signifikan terhadap struktur modal padaperbankan yang terdaftar di Bursa Efek Indonesia periode 2008-2016.

2. Ukurang perusahaan (SIZE) terbukti memiliki pengaruh signifikan terhadap struktur modal padaperbankan yang terdaftar di Bursa Efek Indonesia periode 2008-2016.

3. Tangibility (TANG) terbukti memiliki pengaruh signifikan terhadap struktur modal padaperbankan yang terdaftar di Bursa Efek Indonesia periode 2008-2016. 
4. Pertumbuhan perusahaan (GROWTH) terbukti tidak memiliki pengaruh signifikan terhadap struktur modal padaperbankan yang terdaftar di Bursa Efek Indonesia periode 2008-2016.

5. Profitabilitas, ukuran perusahaan, tangibility, dan pertumbuhan perusahaan secara simultan terbukti memiliki pengaruh signifikan terhadap struktur modal padaperbankan yang terdaftar di Bursa Efek Indonesia periode 2008-2016.

Berdasarkan hasil penelitian, saran bagi para investor adalah variabelvariabeltersebut dapat dijadikan pertimbangan sebelum melakukan investasiuntuk dapat mengetahui bagaimana pengaruh variabel tersebut terhadappenentuan struktur modal suatu perusahaan, sehingga dapat mengurangikemungkinan risiko yang akan terjadi serta untuk mengetahui return yang akandiperoleh investor.Sementara itu, bagi perusahaan disarankan bahwa seorang manajer keuangan dapatmengambil keputusan pendanaan yang tepat berkaitan dengan penentuan strukturmodal. Selain mempertimbangkan variabel-variabel yang dapat mempengaruhistruktur modal, penting bagi manajer keuangan untuk mempertimbangkan analisissubyektif serta mengetahui teori-teori yang berkaitan denganpenentuan struktur modal.

\section{J. Daftar Pustaka}

Abor, J., dan Biekpe, Nicholas, (2007). Corporate governance, ownership structure and performance of SMEs in Ghana: implications for financing opportunities", Corporate Governance: The international journal of business in society, Vol. 7, Issue. 3, pp.288-300.

Afza, Talat.,dan Amer Hussain. (2011). Determinants of Capital Structure: A Case Study of Automobile Sector of Pakistan. Interdisciplinary Journal of Contemporary Research in Business, ISSN: 2073-7122, Vol.2, Issue.10, pp.219-230.

Almeida, Heitor dan Campello, Murillo. (2007). Financial Constraints, Asset Tangibility, and Corporate Investment. Review of Financial Studies, Vol. 20, Issue. 5, pp. $1429-1460$.

Benito, A. (2003). The Capital Structure Decisions of Firms: Is There a Pecking Order?. Banco De Espana Working Paper Series, No. 0310.

Booth L., Aivazian, V.A., Kunt-Demiguc dan Maksimovic, V. (2001). Capital structure in developing countries. Journal of Finance, Vol.56,pp.7-130.

Caglayan, E., dan Sak, N. (2010). The Determinants of Capital Structure: Evidence from the Turkish Banks. Journal of Money, Investment and Banking, Vol.15, hal. $1-9$.

Cassar, G., dan Holmes, S. (2003). Capital structure and financing of SMEs: Australian evidence. Journal of Accounting and Finance, Vol.43, No.2, pp.123-47.

Deesomsak, R., Paudyal, K., dan Pescetto, G. (2004) The determinants of capital structure, evidence from the Asia Pacific region, Journal of Multinational Financial Management. Vol 14, pp. 387-405.

Fahmi, Irham. (2012). Analisis Laporan Keuangan. Cetakan Ke-2. Bandung: Alfabeta.

Hermuningsih, Sri. (2013). Profitability, Growth Opportunity, Capital Structure and The Firm Value. Journal of Economic Literature.

Horne, James C.V., dan John, M. W. (2012). Prinsip-prinsipManajemen Keuangan, (Edisi 13). Jakarta : Salemba Empat.

Jung, Kooyul., Kim Yong-Cheol., dan Stulz, René. (2010). Timing, investment opportunities, managerial discretion, and the security issue decision. Journal of Financial Economics, Vol. 42, Issue. 2, pp. 159-185.

Karadeniz, E., Kandir, S.Y., Balcilar, M., dan Onal, Yildrim. (2009). Determinants of capital structure:evidence from Turkish lodgingcompanies. International Journal ofContemporary HospitalityManagement, Vo.21, No.5, pp. 591-609. 
Kayo, Eduardo K. And Kimura, Herbert. (2010). Hierarchical determinants of capital structure. "Journal of Banking \& Finance", 35, 358-371.

Krasker,W.S. (1986). Stock Price Movements in Response to Stock Issues under Asymmetric Information. Journal of Finance, Vol. 41, Issue. 1, pp. 93-105.

Luqman Hakim \& Nardi Sunardi (2018) Determinant of Leverage And It's Implication on Company Value of Real Estate And Propertysector Listing In IDX Period Of 20112015, Man In India, 97 (24) : 131-148, Serials Publications.

Myers, S., dan N. Majluf. (1984). Corporate financing and investment decisions when firms have information investors do not have. Journal of Financial Economics, Vol. 13, pp.187-222.

Nardi Sunardi (2017) Determinan Kebijakan Utang Serta Implikasinya terhadap Kinerja Perusahaan (Perusahaan yang tergabung dalam indeks LQ.45 yang terdaftar di Bursa Efek Indonesia Tahun 2011- 2015) Jurnal Sekuritas, Vol. 1, No.1 / September 2017 Universitas Pamulang.

Nardi Sunardi, Aceng Abdul Hamid, Lativa, Abdul Kadim, Natanael Tulus (2018) Determinant Of Cost Efficiency And It's Implications For Companies Performance Incorporated In The Lq.45 Index Listing In Idx For The Period of 2011-2016, International Journal of Applied Business and Economic Research,.Volume 16, Number 1, 2018, ISSN : 0972-7302

Smith, C.W., dan R.L. Watts. (1992). The Investment Opportunity Set and Corporate Financing, Dividend, andCompensation Policies. Journal ofFinancial Economics, Vol.32, pp.263-292.

Sundjaja, Ridwan S., dan Barlian, Inge D. (2007). Manajemen Keuangan. Edisi 6 (Buku 1). Jakarta: Literata Lintas Media.

Titman, S., dan Wessells, R. (1988). The determinants of capital structure choise. The Journal of Finance, Vol.43, pp.1-19.

Uglurlu, M. (2000). Agency costs and corporate control devices in the Turkish manufacturing industry. Journal of Economic Studies, Vol. 27, No.6, pp.566-99.

Widodo, W., Moeljadi, dan Djawahir, A. Helmy. (2014). Pengaruh Tangibility, Profitabilitas, Pertumbuhan Perusahaan, Non DebtTax Shields, Cash Holding dan Ukuran Perusahaan terhadap StrukturModal Perusahaan (Studi pada Perusahaan Manufaktur yang Listingdi BEI Tahun 2010-2012). JurnalAplikasi Manajemen, Vol. 12, No. 1. 